\title{
Esophageal intramural pseudodiverticulosis as a diagnostic and therapeutic problem
}

\author{
Magdalena Szczęsna, Juliusz Gątarek, Tadeusz Orłowski \\ Department of Surgery, National Research Institute of Tuberculosis and Lung Diseases, Warsaw, Poland \\ Kardiochirurgia i Torakochirurgia Polska 2016; 13 (3): 265-268
}

\begin{abstract}
The article presents the case of a 68-year-old patient with alcohol dependence syndrome, who was admitted, in serious condition, to the Department of Surgery due to esophageal intramural lesions of unclear etiology. The imaging studies showed no signs of transmural perforation of the esophageal wall. Esophagogastroscopy revealed intramural fluid reservoirs and small oval cavities with smooth edges in the esophageal mucosa. The patient was treated conservatively with parenteral nutrition and rehabilitation. Subsequently, the patient was transferred to the intensive care unit because of cardiorespiratory failure. Despite adequate pharmacological treatment, the patient died.
\end{abstract}

Key words: esophageal intramural pseudodiverticulosis, diseases of the esophagus.

\section{Introduction}

Esophageal intramural pseudodiverticulosis (EIP) is a rare condition of unclear etiology. It can coexist with gastroesophageal reflux disease, inflammatory diseases of the esophagus (including candidiasis), esophageal stenosis, as well as diabetes, alcohol dependence syndrome, achalasia, Mallory-Weiss syndrome, Crohn's disease, or tuberculosis [1-4]. Structurally, the diverticula develop due to widening of the secretory ducts of the submucosal glands, which is why they are not true diverticula [5].

There are no symptoms typical of EIP. The patients most often complain of dysphagia. The most commonly used diagnostic procedures in this context include endoscopy, which demonstrates the presence of small round cavities in the esophageal wall, and contrast radiography, which shows a specific symptom in the form of small bottle/flaskshaped protrusions in the mucous membrane [3, 5]. Combined with the patient's clinical presentation, computed tomography and endoscopic ultrasonography may also be useful in diagnosing EIP.

The treatment includes the use of anti-inflammatory agents in combination with therapy for diseases coexist-

\section{Streszczenie}

W pracy przedstawiono przypadek 68-letniego pacjenta z zespołem zależności alkoholowej w wywiadzie, który w stanie ciężkim trafił do Kliniki Chirurgii z podejrzeniem niepełnościennego uszkodzenia przełyku o nieznanej etiologii. W badaniach obrazowych nie stwierdzono cech pełnościennej perforacji ściany przełyku. W ezofagogastroskopii wykazano śródścienne zbiorniki płynowe oraz drobne owalne ubytki śluzówki przełyku o równych, gładkich brzegach. Pacjenta leczono zachowawczo, ponadto stosowano żywienie pozajelitowe i rehabilitację usprawniającą. Następnie leczenie kontynuowano na oddziale intensywnej terapii z powodu wystąpienia niewydolności krążeniowo-oddechowej. Pacjent zmarł pomimo stosowania leczenia farmakologicznego.

Słowa kluczowe: pseudouchyłkowatość przełyku, choroby przetyku.

ing with EIP. However, regression of the changes is not observed despite appropriate treatment.

\section{Case report}

A 68-year-old male smoker, suffering from alcohol abuse and alcoholic cirrhosis, was transferred to the Surgery Clinic of the Institute of Tuberculosis and Lung Diseases with the diagnosis of nontransmural esophageal injury of unclear etiology.

The obtained medical records of the patient included esophagoscopy results, which indicated the presence of openings suggesting the existence of an esophagobronchial fistula $30 \mathrm{~cm}$ from the incisors. However, computed tomography (CT) did not confirm the presence of a fistula. No signs of mediastinitis or fluid in the pleural cavities were found. The examination did reveal concentric thickening of the whole length of the esophageal wall (up to $9 \mathrm{~mm}$ ) and air-filled vesicles within the wall (Figs. 1 A, B). Furthermore, liver cirrhosis and cecal wall thickening were revealed.

The results of an X-ray examination with non-barium contrast included in the records demonstrated the presence of a reservoir filling with contrast (18 $\mathrm{mm}$ in length)

Address for correspondence: Magdalena Szczęsna MD, Department of Surgery, Institute of Tuberculosis and Lung Diseases, 26 Płocka St, 01-138 Warsaw, Poland, phone: +48 2243122 76, e-mail: m.d.szczesna@gmail.com

Received: 23.12.2014, accepted: 18.08.2016. 

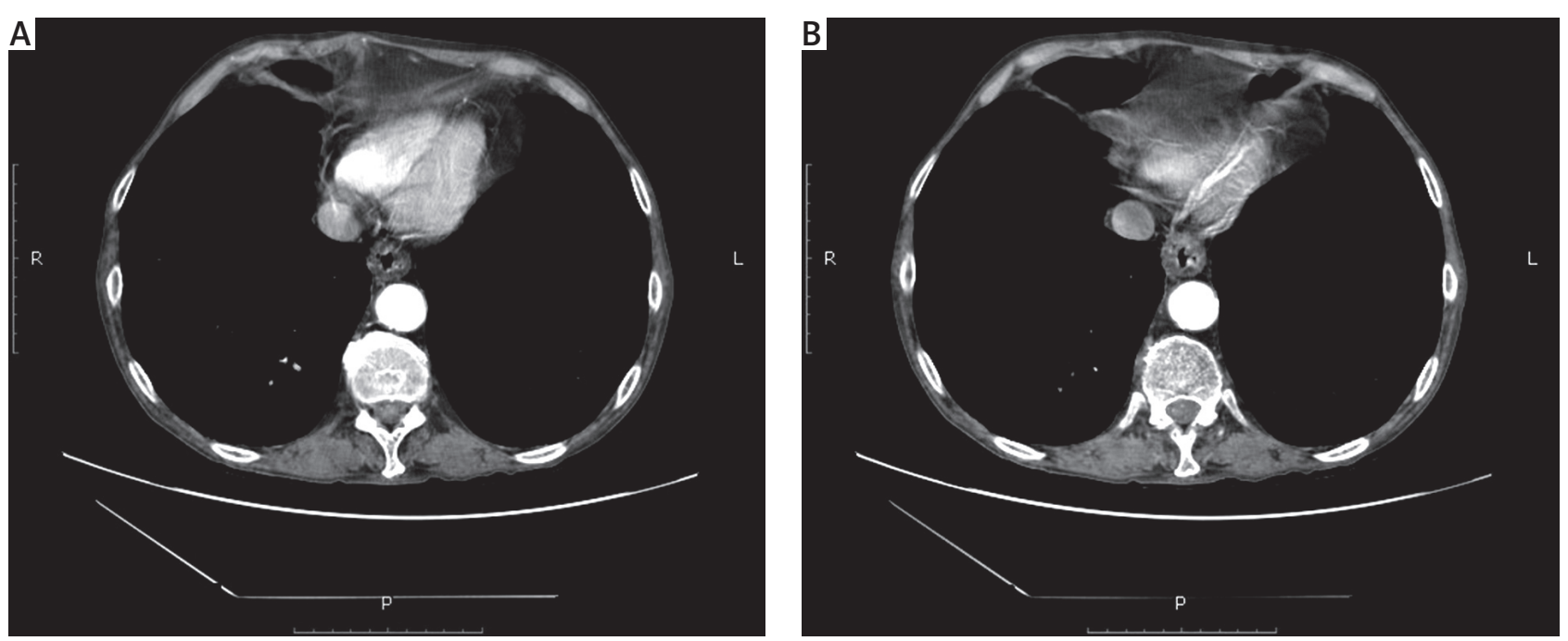

Fig. 1 A, B. Computed tomography scans of the thickening the esophageal wall and air-filled vesicles within the wall

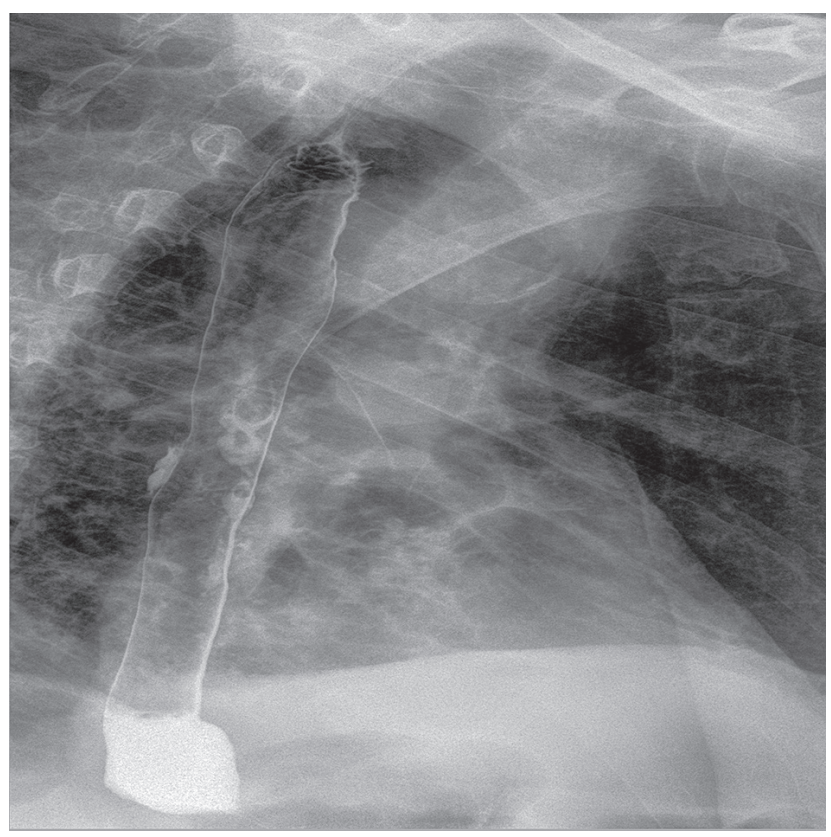

Fig. 2. Thoracic $\mathrm{X}$-ray of a reservoir filling with contrast

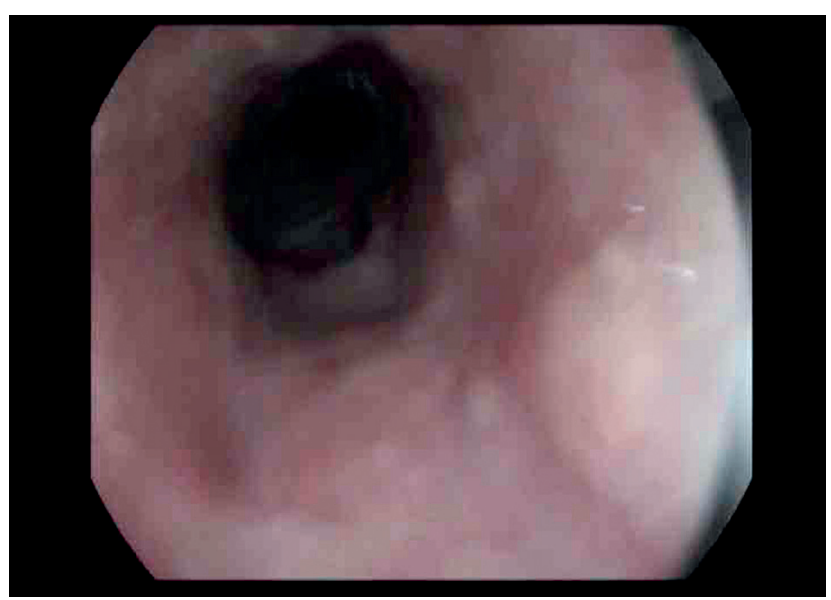

Fig. 3. Small protrusions of the esophageal mucosa at the level of the gas vesicles in the esophageal wall that were visualized by CT (Fig. 2).

On admission to the clinic, the patient's condition was severe. He complained of significant fatigue. Laboratory investigation revealed anemia, thrombocytopenia, hyponatremia, hypokalemia, hypocalcemia, hypomagnesemia, hypoalbuminemia, prolonged coagulation time, and increased C-reactive protein (CRP) concentration. The initial diagnosis considered non-transmural esophageal wall injury caused by a foreign body. However, the patient did not report swallowing any foreign bodies, making this diagnosis unlikely. Esophagogastroscopy revealed small protrusions of the mucosa approximately $35 \mathrm{~cm}$ from the incisors (Fig. 3). When a section of one of the lesions was acquired, white fluid effused from within, leaving behind a small cavity in the mucosa, which suggested that an intramural fluid-filled reservoir was emptied. Additionally, in the segment from $30 \mathrm{~cm}$ to $37 \mathrm{~cm}$, shallow oval cavities were found in the mucosa (approximate dimensions of the largest one: $16 \times 8 \mathrm{~mm}$ ); they were most likely the remains of reservoirs which had emptied spontaneously in the past (Figs. 4 A, B). Histopathological examination revealed the presence of inflammatory infiltrate without signs of atypia. Mycobacterial and fungal staining was negative. Bacterioscopy showed no acid-fast mycobacteria.

The patient was treated conservatively; he received antibiotic therapy and treatment for electrolyte disorders. He was fed parenterally and underwent physical therapy. On the $4^{\text {th }}$ day of hospitalization, after control esophagogastroscopy was performed, showing that the esophageal lesions were stable, a decision was made to gradually introduce oral feeding (liquids and mashed food).

On the $8^{\text {th }}$ day of hospitalization, the patient's general condition began to gradually deteriorate, with oxygen saturation falling to $60 \%$. Diagnosed with respiratory failure, the patient was transferred to the Intensive Care Unit, where he received mechanical ventilation (mode: $\mathrm{BILEVEL} \mathrm{FiO}_{2}$ 0.8, increased over the subsequent days to $\mathrm{FiO}_{2}$ 1.0). Control CT 

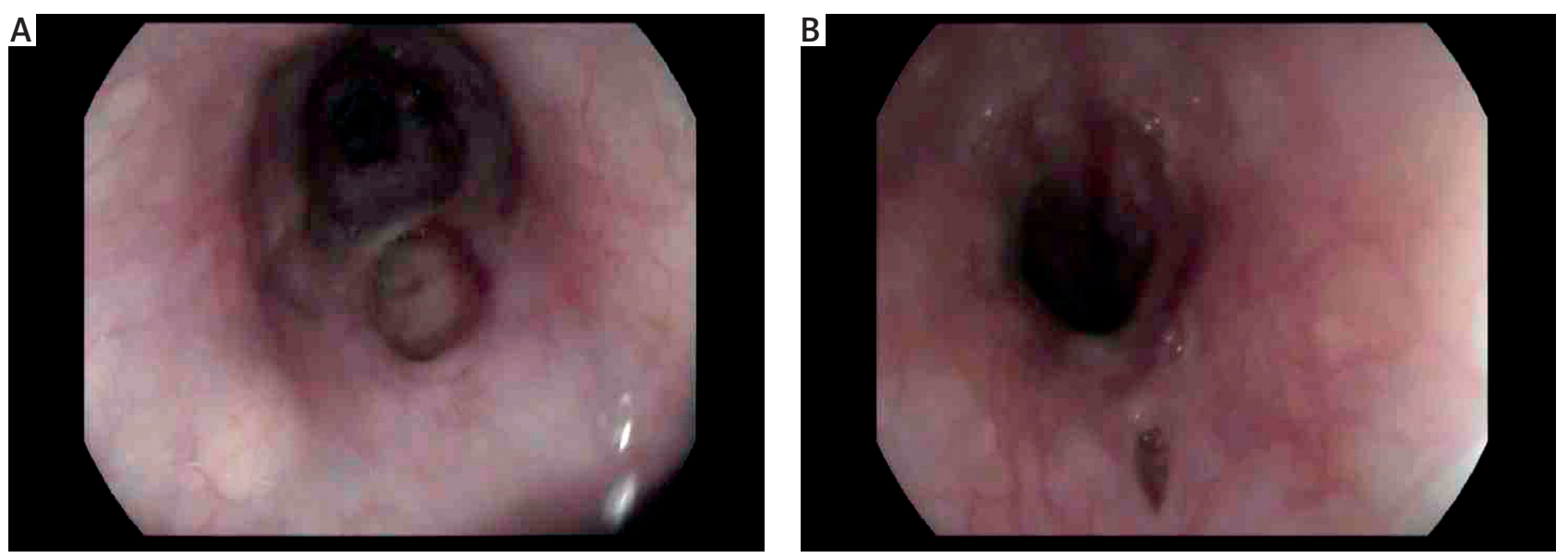

Fig. 4 A, B. Small cavities in the esophageal mucosa
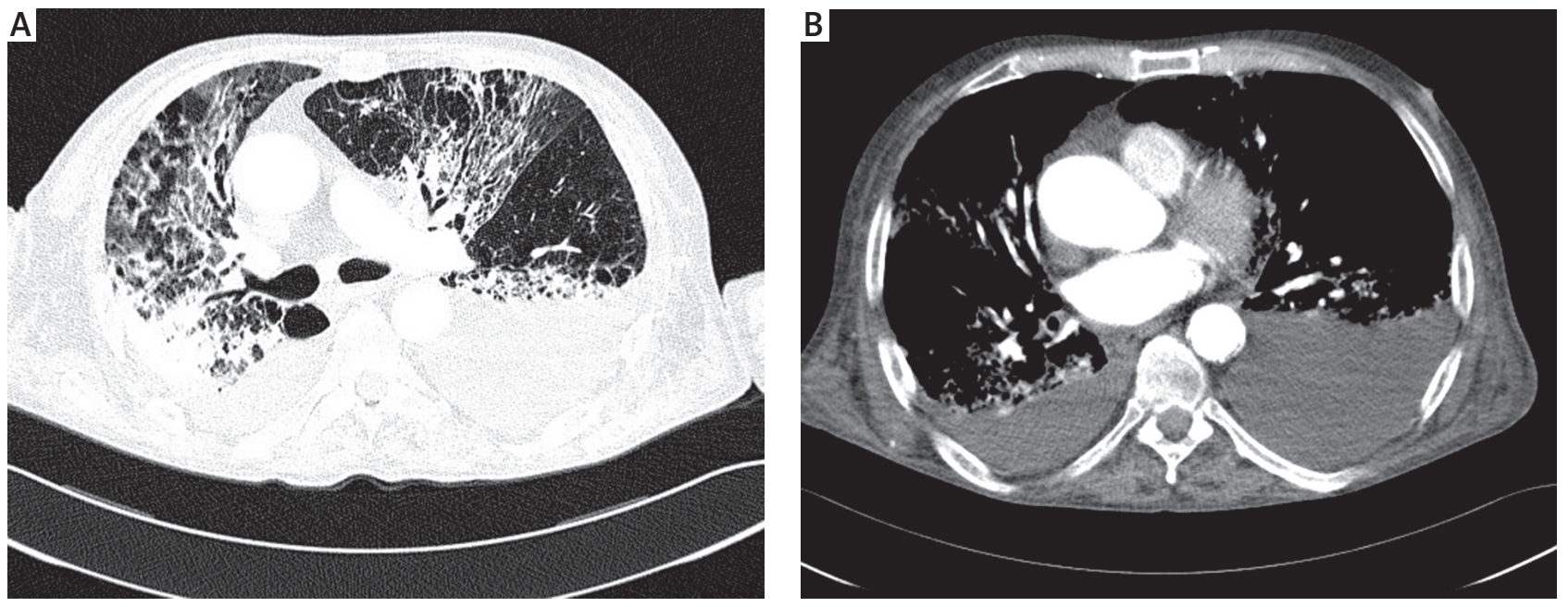

Fig. 5 A, B. Areas of increased parenchymal density. Emphysema. Fluid in both pleural cavities. Concentric thickening of the esophageal wall

did not show signs of transmural esophageal perforation; the esophageal walls were concentrically thickened, but to a lesser degree than that showed by the previous examination. No fluid pockets or adipose tissue edema was found in the mediastinum. Fluid appeared in both pleural cavities (especially on the left side). Bilaterally, areas of increased parenchymal density overlapped with emphysematous lung parenchyma, and ascites was diagnosed (Figs. 5 A, B).

Investigation of bronchial aspirate cultures revealed the presence of Enterococcus faecalis and mold fungi. Targeted antibiotic treatment was started, and the left pleural cavity was drained.

Despite the treatment, the general condition of the patient continued to gradually deteriorate. On the $14^{\text {th }}$ day of his stay at the intensive care unit (ICU), the patient died due to severe cardiorespiratory failure.

\section{Discussion}

Esophageal intramural pseudodiverticulosis is a rare condition which was first described by Mendl in 1960 [6]. Its etiology is still unknown. The EIP has been reported to be associated with gastroesophageal reflux disease, inflammatory diseases of the esophagus (including candidiasis), and esophageal stenosis. Patients with diabetes, alcohol dependence syndrome, achalasia, Mallory-Weiss syndrome, Crohn's disease, tuberculosis, and esophageal injuries caused by caustic agents are also at an increased risk of EIP [3-6]. Although EIP is often associated with benign conditions, several cases of its coexistence with esophageal cancer have also been reported [3].

Structurally, the diverticula develop due to dilatation of the secretory ducts of the submucosal glands, which is why they are not true diverticula [2]. Many authors suggest that the obstruction and subsequent dilatation of the secretory ducts is caused by inflammatory infiltrates from epithelial and mucous cells developing around the ducts and/or by submucosal fibrosis [1-4]. Others underscore that, in cases in which esophageal stenosis and EIP are concomitant, the dilatation of the ducts results from increased intramural pressure in areas proximal to the stenoses [7].

There are no symptoms typical of EIP. The patients most often complain of dysphagia and other symptoms charac- 
teristic of motor disorders, esophageal stenosis, or esophageal reflux [8]. Radiological examinations reveal a specific symptom in the form of small bottle/flask-shaped protrusions of the mucous membrane [5]. The number of pseudodiverticula may vary from less than 5 to more than 20 [1]. Endoscopy may visualize small openings or depressions in the esophageal wall, although, according to the literature, this image is observed in only $20-25 \%$ of EIP cases [1, 3]. Computed tomography examinations reveal characteristic thickening of the esophageal wall with the presence of intramural gas-filled vesicles. Transesophageal ultrasonography may reveal hyperechogenic changes in the wall of the esophagus, corresponding to intramural gas vesicles, as well as thickening of the mucous and submucous membranes (while the lamina muscularis of the esophageal wall remains normal) $[3,9]$.

The following conditions should be considered in EIP differentiation: esophageal wall injury by a foreign body, esophageal intramural abscess in the course of gastrointestinal tuberculosis, esophageal intramural hematomas of various etiology, esophageal perforation, esophageal fistula, and esophageal varices.

In the case of esophageal wall injury by a foreign body, the patient's medical history usually includes the swallowing of a foreign body, and cavities in the esophageal mucosa are usually observed after the foreign body is removed. Furthermore, there are no intramural fluid reservoirs. Microbiological results and clinical data are key when diagnosing a tuberculous abscess in the wall of the esophagus. Concomitant coagulation disorders and, possibly, anticoagulative treatment in the medical history may suggest an intramural hematoma of the esophagus. Perforation may be idiopathic, e.g., as part of the Boerhaave syndrome, or traumatic, e.g. iatrogenic (related to medical procedures). In contrast to changes associated with EIP, perforation is transmural and typically presents as a linear rupture and not an oval opening in the mucosa (as is the case in EIP). In the case of tracheoesophageal or bronchoesophageal fistulas, the patients complain of aspiration while drinking. Endoscopic examinations of the esophagus and the bronchial tree are key in confirming the diagnosis. When esophagomediastinal, esophagopulmonary, or esophagopleural fistulas are diagnosed, esophagoscopy is supplemented with imaging examinations such as CT and contrast X-ray examinations of the esophagus. The presentation of EIP may be similar to that associated with esophageal varices. In the case of both conditions, imaging examinations may show protrusions in the esophageal mucosa; however, in endoscopic examinations, varices have a characteristic livid color, and their rupture results in bleeding. In the case of EIP, the rupture of a submucosal gland duct distended with secretion results in effusion of whitish fluid.

Therapy most often consists in the treatment of esophageal inflammation and conditions concomitant with EIP, including antibiotic treatment [3]. Some authors report that, in patients with concomitant esophageal stenosis, endoscopic dilatation reduces the symptoms of EIP. However, long-term observations show no regression of diverticulosis despite appropriate treatment and improvements in the general condition of the patients $[3,10]$.

\section{Disclosure}

Authors report no conflict of interest.

\section{References}

1. Chon YE, Hwang S, Jung KS, Lee HJ, Lee SG, Shin SK, Lee YC. A case of esophageal intramural pseudodiverticulosis. Gut Liver 2011; 5: 93-95.

2. Sabanathan S, Salama FD, Morgan WE. Oesophageal intramural pseudodiverticulosis. Thorax 1985; 40: 849-857.

3. De Oliveira LL, Carneiro FOAA, Baba ER, Vilaca TG, Chaves DM, Almeida Artifon EL, Moura EGH, Sakai P. Esophageal intramural pseudodiverticulosis: a rare endoscopic finding. Case Rep Med 2013; 2013: 154767.

4. O'Connor OJ, Brady A, Shanahan F, Quigley E, O'Riordain M, Maher MM. Esophageal intramural pseudodiverticulosis characterized by barium esophagography: a case report. J Med Case Rep 2010; 4: 145.

5. Konturek SJ. Gastroenterologia i hepatologia kliniczna. PZWL, Warszawa 2006.

6. Mendl K, Tanner $\mathrm{CH}$. Intramural diverticulosis of the oesophagous and Rokitansky-Aschoff sinuses in the gall bladder. Br J Radiol 1960; 33: 496-501.

7. Long JD, Orlando RC. Esophageal submucosal glands: structure and function. Am J Gastroenterol 1999; 94: 2818-2824.

8. Brandt LJ. Esophageal intramural pseudodiverticula with endoscopic and radiographic demonstration of intramural trackings. Gastrointest Endosc 2009; 70: 383-385.

9. Devereaux CE, Savides TJ. EUS appearance of esophageal pseudodiverticulosis. Gastrointest Endosc 2000; 51: 228-231.

10. Liu SM, Wu HH, Chang KK, Tseng LJ, Han SC, Mo LR. Esophageal intramural pseudodiverticulosis complicated with stricture. J Formosan Med Assoc 2010; 109: 241-244. 